\title{
Openness of innovation systems through global innovation networks: a comparative analysis of firms in developed and emerging economies
}

\author{
Prof. Helena Barnard
}

GIBS, U. Pretoria, PO Box 787602, 2146 Johannesburg, South Africa

Prof. Cristina Chaminade*

Dept. Economic History, School of Economics and Management, Lund University, PO Box 117, 22100 Lund, Sweden

This version: October 2016

\begin{abstract}
In the last decade we have witnessed an unprecedented growth in the globalization of innovation activities and more specifically, of global innovation networks (GINs) extending into middle-income countries. However, hitherto most of the literature is either theoretical or based on a handful of cases. We do not know what are the different forms of openness through networks in which firms participate, whether in terms of the various degrees of global scope, innovativeness and network scope, or other key characteristics. This exploratory paper provides empirical evidence of the different forms of openness through global innovation networks used by firms located in mature and emerging innovation systems. The paper relies on survey-based firm-level data collected in five European countries plus Brazil, South Africa, India and China.
\end{abstract}

Key words: Globalization, innovation networks, Europe, South Africa, Brazil, China, India

*Corresponding author: Tel. +27 11771 4000/4213

Email addresses: barnardh@gibs.co.za (H. Barnard), Cristina.chaminade@ekh.lu.se (C. Chaminade)

This is a preprint version of an article published in the International Journal of Technological Learning, Innovation and Development (IJTLID). Any citations to this paper should be as follows:

Barnard, H.; Chaminade, C. (2017) Openness of innovation systems through global innovation networks: a comparative analysis of firms in developed and emerging economies. Accepted for publication in the Int. J . of Technological Learning, Innovation and Development (IJ TLID). 


\section{Introduction}

A decade ago the UNCTAD published a report on R\&D Foreign Direct Investment which pointed out, almost for the first time, the changing role of middle-income countries in the global flows of innovation-related investments (UNCTAD, 2006). It showed how R\&D investments to and from middle-income countries had increased dramatically in just in a few years. Since then, a growing number of studies have been trying to understand the drivers, consequences and dynamics of the new global configuration of innovation activities through a variety of lenses: global value chains (Dedrick, Kraemer, \& Linden, 2009; Timmer, Erumban, Los, Stehrer, \& de Vries, 2014), global production networks (Ernst, 2009; Yeung \& Coe, 2014) and more recently global innovation networks (Cooke, 2013a, 2013b).

Hitherto, the internationalization or globalization of innovation has been studied from a variety of disciplines. The international business literature has contributed to our understanding on why multinationals from developed countries locate R\&D activities abroad (J. Cantwell \& L. Piscitello, 2005; John Cantwell \& Lucia Piscitello, 2005; Kuemmerle, 1999; Pearce, 1999; Rodriguez, 2011), while economic geographers and innovation scholars have highlighted the networked character of innovation at a global scale (Coe \& Bunnell, 2003; Gertler \& Levitte, 2005; OECD, 2008; Zander, 1999). However, most empirical evidence is based either on a small number of qualitative case studies of large multinational companies, on patent data (Cantwell \& Piscitello, 2002; Cantwell, 2004; Cantwell \& Odile, 2000; Cantwell \& Piscitello, 2007; Gerybadze \& Reger, 1997; Saliola \& Zanfei, 2009) or strategic alliances by large firms (Hagedoorn, 1993; R. Narula \& Hagedoorn, 1999). What emerges from the international business literature and innovation studies is a story of the globalization of innovation driven virtually exclusively by large multinational corporations (MNCs) with their headquarters in developed countries (Parrilli, Nadvi, \& Yeung, 2013). The UNCTAD report (2006) suggests that this may be changing and we may be witnessing the emergence of other forms of global innovation networks, driven by a variety of actors (large and small, multinational and standalone firms) from both high and middle-income economies.

A global innovation network can be defined as a globally organized web of collaborative interactions between different organisations (firms and/or non-firm organisations) engaged in knowledge production that is related to and resulting in innovation.

This paper considers the degree of globalness, networkedness and innovativeness of the linkages in which firms in both high and middle-income countries are engaged to explore the diversity of networks that characterize open innovation systems. Approaching this research task requires the collection of data that includes both MNCs and non-MNCs, internal and external networks, small and large firms and from high- and middle-income countries. This has not been done until now.

Using firm-level data collected through a survey in 2010 in five European countries as well as Brazil, China, India and South Africa, this paper provides an empirical overview of the different types of engagement of firms in global innovation networks, the role of different actors such as MNCs and non-MNCs, as well as larger and smaller firms in global innovation networks, and importantly the role of firms located in high- and middle-income countries in such networks.

The paper is structured as follows. Section 2 presents the main analytical framework relative to global innovation networks. Section 3 introduces the main data used for the study as well as the results of the analysis on the degree of global scope, innovativeness and network scope that allows us to identify different forms of GINs. The different forms of GINs that emerge from the analysis are presented and discussed in section 4 . Finally, section 5 
concludes with a discussion on the implications of the results for a research agenda on globalization of innovation.

We find evidence that $12.2 \%$ of our sampled firms engaged in one or another form of global innovation networks thus pointing out to the openness of the NIS considered. The findings also show that "global networkers" and "networkers" are the most widespread forms of GINs, with 3.95\% and 3.29\% respectively. Our evidence suggests that GINs resemble existing phenomena as global production networks and internationalized R\&D in terms of main actors and geographical scope, but that there are also important differences that suggest that GINs are a new emerging phenomenon. We find that firms located in national innovation systems in middle-income countries (and especially India) are most likely to participate in GINs that operate beyond the Triad. Although many GINs involve MNCs, we also find a significant number standalone firms are involved in GINs. Similarly, although many GINs involve firms with 1000 plus employees, a substantial number of firms involved in GINs are smaller - 250-999 or even fewer employees. All-in-all, our findings indicate that there is a large variety of actors engaging in GINs and confirm that firms in middle-income countries are indeed emerging as participants in global innovation. In terms of organisational form, our findings suggest that firms need not be MNCs in order to be part of such global networks.

\section{Conceptual framework}

The internationalization of innovation activities is not a new phenomenon. Firms have long commercialized their new products and processes in international markets(Archibugi \& Michie, 1995; Le Bas \& Sierra, 2002), have engaged in research collaboration beyond national boundaries (Hagerdoorn, 1990; Howells, 1990) and have located R\&D activities in other countries(John Cantwell \& Lucia Piscitello, 2005; Cantwell \& Piscitello, 2007; Dunning \& Lundan, 2009). So, is this "new" literature on global innovation networks old wine in new bottles or is it genuinely a new phenomenon that deserves further attention?

In terms of the internationalisation of R\&D, the empirical evidence at both macro (Castellacci \& Archibugi, 2008) and micro level (Cantwell, 2000; Cantwell \& Janne, 1999; Cantwell \& Santangelo, 2002; John Cantwell \& Lucia Piscitello, 2005; Gerybadze \& Reger, 1997; Rajneesh Narula \& Zanfei, 2004; Sabiola \& Zanfei, 2009) suggests that the majority of inbound and outbound R\&D flows have traditionally taken place between the technologically and economically advanced high-income countries and have been driven virtually exclusively by large MNCs with their headquarters in high-income countries. So although it is true that innovation has been long an international phenomenon, it has hardly been a global one.

However, for a number of reasons this may be changing. The R\&D flows to and from middle-income countries generally have increased substantially in the last decade (Amighini, Sanfilippo, \& Rabellotti, 2010; Barnard, 2011; Ramamurti \& Singh, 2009; UNCTAD, 2006). One of the main arguments explaining this global shift of innovation activities is the accumulation of capabilities in certain developing countries and regions are facilitating the emergence of new forms of global innovation networks rather than the one that dominates the literature on internationalization of R\&D (Chaminade \& Vang, 2008). Simply put, middleincome countries are better able to contribute to innovation than ever before ${ }^{1}$.

We still expect differences in the nature of innovation activities conducted in GINs by firms from high and middle-income countries. The proportion of firms introducing innovations that are new to the firm versus new to the world varies significantly between high-income and middle-income countries (Fifarek \& Veloso, 2010). Most of the new to the

\footnotetext{
${ }^{1}$ In addition, because of their steady economic growth, many middle-income countries have become more attractive to MNCs struggling with the fall-out from the 2008 global economic crisis in traditional locations such as Europe, the USA and Japan.
} 
world innovations are implemented by firms headquartered in the high income countries and product innovations in middle-income countries are often behind the technological frontier: it is mainly imitative innovation, more related to the acquisition of technology developed somewhere else and is typically concerned with adaptation to the local needs rather than to the development of new products (M. Bell \& Pavitt, 1993; Martin Bell \& Pavitt, 1995; Coe \& Bunnell, 2003; Edquist, 2005). Following the logic expressed in this literature, we might expect that new to the world innovations will continue to take place in networks dominated by firms from high-income countries while firms in middle-income countries will use their innovation networks to acquire existing technology that will be further introduced in the firm.

To the extent that the global scope can be taken to mean a geographical spread that is confined to a specific geographical area like the Triad or truly global (Dicken, 2007), network scope can refer to the existence of networks that are internalized, externalized or both (D. Castellani \& Zanfei, 2006) and innovativeness can refer to degrees of novelty, from new to the firm to new to the world, GINs in which firms are engaged can vary according their degrees of global scope, network scope or innovativeness. For example, a European MNC locating an R\&D lab in another European country to adapt the product to the local market could be a GIN that is more regional ${ }^{2}$ than global, more internally networked than externally and only incrementally innovative. On the other side of the spectrum, we may encounter a US firm that is investing in the development of a completely new to the world bio-fuel in India with inputs coming from a firms in China and a university in Germany, which is a GIN that is highly global, highly networked (internalized and externalized) and highly innovative.

Exploring the openness of national innovation systems in developed and developing countries in terms of the variety of GINs in which firms are engaged as well as the nature of actors participating in those networks is the objective of this paper.

\section{Methodological design}

\subsection{Ingineus survey and data base}

This paper relies on a survey conducted across nine countries under the auspices of the EUfunded INGINEUS project. Data on firms in Europe were gathered from leading economies with a per capita income above US\$ 45000 per year, namely Denmark, Germany, Norway and Sweden. Estonia, a transition economy was also polled ${ }^{3}$, as well as four prominent middle-income countries: Brazil, China, India and South Africa. The choice of countries allows a clear comparison between economies that are global leaders and ones that are largely followers in the global arena. The survey for each country focused on either ICT, automotive or agro-processing ${ }^{4}$, whichever sector was of economic importance in that country ${ }^{5}$.

Because one of the goals of the INGINEUS project was to extend insights about GINs beyond large multinationals from high-income countries, the choice of datasets was

\footnotetext{
${ }^{2}$ Regional meaning here supra-national regions, like the European union

${ }^{3}$ Estonia is an unusual case, based in Europe but with a similar level of development as the middle-income countries. It contributes only 17 out of 1215 data points, and does not meaningfully affect the results.

${ }^{4}$ Sweden had both auto and ICT surveys.

${ }^{5}$ The sectors were chosen to represent an old industry with low research intensity (agro-processing), a more established industry with a medium level of research intensity (automotive) and the young, highly researchintensive industry, ICT, that is argued to be a key driver of changes in how firms organise. One of the insights from the survey, not the focus of this paper, is that the supply chain has fragmented to the extent that there are more and less research intensive activities, as well as significant ICT investment in any given industry. This raises important questions about industry selection for future studies.
} 
complicated. Where possible, a sample frame was established by using existing databases, e.g. Statistics Sweden or the German commercial database Hoppenstedt. This was not always possible, especially for the middle-income countries. There the strategy was to combine existing (but often out-of-date or inadequate) databases, e.g. in Brazil the database of the automotive union SINDIPECAS, the official Annual Registry of Social Information (RAIS) and information from large automotive firms about their suppliers was used to compile a sample frame $^{6}$. All databases were filtered to ensure that firms with five or more employees were contacted. The questionnaire therefore encompasses both publicly listed and private firms.

The information gathering also took place in a variety of different ways. In countries with a culture of participating in surveys, e.g. the Scandinavian countries, firms were sent a link to an online tool. In the middle-income countries, data gathering was done best telephonically or through face-to-face interviews. In all sectors and across all countries 1215 responses were collected.

Table 1 offers a summary of the results received from each sector and each country, the number of responses and response rates. The combined INGINEUS sample was dominated by ICT responses. This is in part due to the size of India and China, but also due to the more established and thus concentrated nature of the agro-processing and auto industries. Although China has the second-highest number of responses, it also has the lowest response rate $(2.7 \%)$. This is because the Chinese team had opted to choose a broader sample and use a less labour-intensive strategy for targeting respondents. The low German response rate is most likely due to the fact that the questionnaire was sent out during a period when the German automotive industry was struggling with the economic crisis.

Table 1: Survey results by country and industry (number of responses; response rates in brackets)

\begin{tabular}{|l|l|l|l|l|}
\hline Countries & ICT & Auto & Agro & TOTAL \\
\hline Brazil & & $69(25.9 \%)$ & & \\
\hline China & $243(2.7 \%)$ & & & \\
\hline Estonia & $17(14 \%)$ & & & \\
\hline India & $324(20.2 \%)$ & & & \\
\hline South Africa & & & $84(16.9 \%)$ & \\
\hline $\begin{array}{l}\text { TOTAL middle- } \\
\text { income countries }\end{array}$ & $\mathbf{5 8 4 ( 5 . 3 4 \% )}$ & $\mathbf{6 9}(\mathbf{2 5 . 9 \% )}$ & $\mathbf{8 4}(\mathbf{1 6 . 9 \% )}$ & $\mathbf{7 3 7}(\mathbf{6 . 3 2 \% )})$ \\
\hline Denmark & & & $49(23.3 \%)$ & \\
\hline Germany & $181(11.9 \%)$ & & & \\
\hline Norway & $171(10.3 \%)$ & $24(14.3 \%)$ & & \\
\hline Sweden & $\mathbf{3 5 2 ( 1 1 . 0 5 \% )}$ & $\mathbf{7 7}(\mathbf{6 . 1 8 \% )}$ & $\mathbf{4 9}(\mathbf{2 3 . 2 \% )}$ & $\mathbf{4 7 8 ( 1 0 . 5 9 \% )}$ \\
\hline $\begin{array}{l}\text { TOTAL high-income } \\
\text { countries }\end{array}$ & $\mathbf{9 3 6 ( 6 . 5 9 \% )}$ & $\mathbf{1 4 6}(\mathbf{1 0 . 6 4 \% )}$ & $\mathbf{1 3 3 ( 1 8 . 5 8 \% )}$ & $\mathbf{1 2 1 5}(7.5 \%)$ \\
\hline Total & & & & \\
\hline
\end{tabular}

However, the most important driver of response rate is probably the initial methodological decision to define possible participants for the survey very broadly. This may have resulted in both a somewhat lower response rate and a somewhat biased sample, e.g.

\footnotetext{
${ }^{6}$ See http://www.ingineus.eu/UserFiles/INGINEUS D2.2_MethodologyReport(1).pdf for more detail about the data gathering process.
} 
some of the smaller firms declined to be polled because they did not consider themselves innovative or global enough to be considered. Although care should therefore be taken in generalising findings, the large number of responses provides confidence that the patterns uncovered are not spurious. In addition, the more inclusive approach allows us to map how smaller firms, standalone firms, and firms located in middle-income countries - previously largely ignored economic actors - participate in GINs.

\subsection{Analysis of global innovation networks}

Even given the usefulness of the dataset, it is important to also engage with the evidence very cautiously. To minimise the false identification of firms involved in global innovation networks, the approach we took to coding data obtained through the INGINEUS survey has been very conservative. The next section describes how we coded the data.

\subsubsection{Global scope}

The global scope measure was based on a question that asked: "Regarding the development of the most important innovation of your firm in the last 3 years: who did you actively collaborate with and in which geographical location?”

The question specified as possible geographical regions the three traditional Triad countries, namely Japan/Australasia, North America and Western Europe, as well as South America, Central and Eastern Europe, Africa and Rest of Asia as the four emerging regions. Regardless of the type of partner, we coded firms as being present in a region if they had at least one type of innovation partner (e.g. laboratory, consultancy or supplier) in that region, i.e. we focus on the geography of the innovation network rather than on the type of partner.

If firms were relying on at least one innovation partner from a Triad country as well as at least one innovation partner from an emerging location, they were coded as global (g). Given our emphasis on innovation beyond the traditional countries, in this paper firms were not coded as global if all their innovation partners were from high-income countries, or (which happened less often) if all their innovation partners were from middle-income countries. The rationale behind this decision was to try to adopt the most strict definition of globalness ${ }^{7}$.

Innovation partners were considered if they were from the firm's home continent but not if they were from the home country. E.g. a Danish firm with a partner in Germany and another one in India would be considered global, but not if the European innovation took place only in Denmark. If firms relied on innovation partners outside their home country from at least two traditional Triad regions, and from at least two middle-income regions, they were coded as highly global (G).

Table 2: Extent of global reach in dataset

\begin{tabular}{|l|c|c|c|c|}
\hline & Total dataset & Total of all G & Total of all g & Total of all Ø \\
\hline Industry breakdown & & & & \\
\hline Agro-processing & 133 & 6 & 16 & 111 \\
\hline Automotive & 146 & 5 & 20 & 121 \\
\hline ICT & 936 & 71 & 127 & 738 \\
\hline
\end{tabular}

\footnotetext{
${ }^{7}$ Adopting a wider definition - for example considering networks in the global North as global, will only increase the amount of observed GINs but it will not influence the question of wether true GINs exist (the wider the parameters, the larger the number of observations inside the parameters).
} 


\begin{tabular}{|l|c|c|c|c|}
\hline & Total dataset & Total of all G & Total of all g & Total of all Ø \\
\hline Location breakdown $^{\mathbf{8}}$ & & & & \\
\hline Middle-income countries & 737 & 69 & 118 & 550 \\
\hline High-income countries & 478 & 13 & 45 & 420 \\
\hline Company type & & & & \\
\hline Standalone company & 693 & 29 & 78 & 586 \\
\hline MNC subsidiary & 246 & 35 & 57 & 154 \\
\hline MNC headquarters & 135 & 18 & 24 & 93 \\
\hline Missing values & 141 & 0 & 4 & 136 \\
\hline
\end{tabular}

Our measure presupposes innovation, so that firms with considerable international activity but little innovation per se or little innovation abroad would not score highly. Using our scoring system, 82 firms in the dataset are highly global (G), reflecting a "sensu stricto" perspective and an additional 163 are global (g), reflecting a "sensu lato" approach. About $80 \%$ of the sample is considered non-global. This measure probably substantially underestimates the trans-national spread of innovation activity, because this paper categorises firms as non-global not only when they do not have any international innovation partners, but also firms with innovation partners in either only high-income or only middle-income countries $^{9}$. Because in this paper we are interested in innovation across Triad and non-Triad partners, a firm with innovation partners in North America, Western Europe and Japan but none in middle-income countries would for example be considered non-global in our analysis ${ }^{10}$. Similarly, a firm with operations in all the middle-income countries and only one of the Triad countries (or vice versa) would be considered global (g), but still not highly global (G).

\subsubsection{Network scope}

There are two components to the network scope measure. The one part of the network scope measure also relies on the question, "Regarding the development of the most important innovation of your firm in the last 3 years: who did you actively collaborate with and in which geographical location?” The question specified as possible collaboration partners clients, suppliers, competitors, consultancy companies, government, local universities/research institutions/laboratories as well as foreign universities/research institutions/laboratories. Regardless of the geographical locations where a partner could be situated, we simply identified whether or not a firm had worked with each partner type to innovate. So, we focus on the breadth of the network in terms of types of partners independently of their location. There was a potential maximum value of 8 for the eight partner types.

This measure only reflects extra-firm partners. But this metric risks biasing the measure against MNCs, because MNCs may operate through a diverse network of differentiated intra-firm subsidiaries. One of the characteristics of the emerging networks is that they draw on a more diverse range of partners than before, but it would be inappropriate to entirely rule out firms with substantial geographically dispersed intra-firm networks.

To counter this potential bias, we also consider the question whether or not firms were offshoring innovation ${ }^{11}$. The question specifies that offshoring can be done both inside the firm (e.g. through the differentiated network of the MNC) or through external partners.

\footnotetext{
${ }^{8}$ Location of the unit that participates in a form of GINs

${ }^{9}$ This paper leaves completely out of estimation any other trans-national activities such as sales or production.

${ }^{10}$ In fact, this occurs virtually never in our dataset, but it is important to note the principle.

${ }^{11}$ The question specified that offshoring encompasses activities both internal and external to the firm for the purposes of serving home country or global markets in a location outside the enterprise's home country. Because
} 
In the measure of network scope, firms were regarded as highly networked $(\mathrm{N})$ if they had indicated that they offshore innovation and if they had also indicated four or more types of network partners with which they work. 149 firms were highly networked. In contrast, firms were regarded as somewhat networked (n) if they indicated that they worked with at least 3 types of network partners, or if they indicated that they offshore innovation. 292 firms were somewhat networked. Again, this measurement reflects respectively the "sensu stricto" and "sensu lato" dimension of different network activities in GINs. This left 774 firms that were coded as not networked because they had indicated that they do not offshore innovation, and had indicated that they work with at most two external network partners.

Table 3: Extent of network scope in dataset

\begin{tabular}{|l|c|c|c|c|}
\hline & Total dataset & Total of all N & Total of all n & Total of all Ø \\
\hline Industry breakdown & & & & \\
\hline Agro-processing & 133 & 9 & 23 & 101 \\
\hline Automotive & 146 & 9 & 33 & 104 \\
\hline ICT & 936 & 131 & 236 & 569 \\
\hline Location breakdown & & & & \\
\hline Middle-income countries & 737 & 133 & 163 & 441 \\
\hline High-income countries & 478 & 16 & 129 & 331 \\
\hline Company type & & & & \\
\hline Standalone company & 693 & 58 & 202 & 433 \\
\hline MNC subsidiary & 246 & 55 & 54 & 137 \\
\hline MNC headquarters & 135 & 36 & 27 & 72 \\
\hline Missing values & 141 & 0 & 9 & 132 \\
\hline
\end{tabular}

\subsubsection{Innovativeness}

In terms of innovativeness, the questionnaire asked about innovation in the following areas:

- New products

- New services

- New or significantly improved methods of manufacturing or producing

- New or significantly improved logistics, distribution or delivery methods for your inputs, goods and services

- New or significantly improved supporting activities for your processes (e.g. purchasing, accounting, maintenance systems etc.)

The responses were divided into two categories. New products and new services were both seen as externally focused innovation (i.e. for a client or customer), and the other three as internally focused (i.e. about improved firm operations).

the simple yes/no question did not adequately differentiate between innovation and offshored production, we relied on the follow-up question where respondents were asked separately for innovation and production about the reason why those activities were offshored. A range of possible reasons are offered (e.g. intellectual property protection or availability of skilled labour), but we disregarded those explanations, and interpreted the question simply as evidence that offshoring of innovation was taking place. If a respondent answered yes to any of the reasons for why innovation was outsourced, we regarded that as an indicator of the presence of a geographically dispersed innovation network. 
Respondents could select new to the firm, new to the industry and new to the world under each of these options. In coding the responses, a scale was developed where "new to the firm" was given a value of 1 , "new to the industry" a value of 2 , and "new to the world" a value of 3 . Scores were calculated for the externally and internally focused types of innovation respectively, and then summed.

The highly innovative firms were those that introduced at least new to the industry innovations or more in both the externally and internally focused innovation categories. Table 4 offers the distribution of firms in the 4 categories.

Table 4: Summary of categorisation into Innovativeness categories

\begin{tabular}{|c|c|c|c|}
\cline { 3 - 4 } \multicolumn{2}{c|}{} & \multicolumn{2}{|c|}{ Internal innovation } \\
\cline { 3 - 4 } & $\begin{array}{c}\text { No innovation or } \\
\text { only New to the firm }\end{array}$ & $\begin{array}{c}\text { New to the industry or } \\
\text { New to the world }\end{array}$ \\
\hline \multirow{2}{*}{ External innovation } & $\begin{array}{c}\text { No innovation or } \\
\text { only New to the firm }\end{array}$ & $\varnothing=656$ firms & $\mathrm{i}=296$ firms \\
\cline { 2 - 4 } & $\begin{array}{c}\text { New to the industry } \\
\text { or New to the world }\end{array}$ & $\mathrm{i}=136$ firms & $\mathrm{I}=128$ firms \\
\hline
\end{tabular}

128 firms, about $10 \%$ of the dataset, met those criteria and were categorised as highly innovative (I). About a quarter of the dataset was not at all innovative, and a similar proportion had only very limited evidence of innovation (e.g. only a "new to the firm" process innovation). For the purpose of this analysis, all 656 these firms were categorised as noninnovative. 431 firms fell between these two extremes. They would for example introduce a "new to the industry" product/service, but only a "new to the firm" internal process. Such firms were categorised as (somewhat) innovative (i). The breakdown of the categories is shown below.

Table 5: Extent of innovativeness in dataset

\begin{tabular}{|l|c|c|c|c|}
\hline & Total dataset & Total of all I & Total of all i & Total of all $\boldsymbol{~}$ \\
\hline Industry breakdown & & & & \\
\hline Agro-processing & 133 & 13 & 35 & 85 \\
\hline Automotive & 146 & 30 & 40 & 76 \\
\hline ICT & 936 & 85 & 356 & 495 \\
\hline Location breakdown & & & & \\
\hline Middle-income countries & 737 & 66 & 307 & 364 \\
\hline High-income countries & 478 & 27 & 44 & 124 \\
\hline Company type & & & & \\
\hline Standalone company & 693 & 86 & 226 & 381 \\
\hline MNC subsidiary & 246 & 28 & 108 & 110 \\
\hline MNC headquarters & 135 & 11 & 86 & 38 \\
\hline Missing values & 141 & 3 & 11 & 127 \\
\hline
\end{tabular}

\subsection{Global innovation networks}

We had adopted a conservative approach to coding throughout. Our measure of global scope excludes firms with global sales, marketing and production footprint - firms had to 
innovate across borders. Moreover, firms had to innovate not only across borders; they had to innovate in both high and middle-income countries, that is, they had to be global. For example, firms with extensive innovation activities in North America, Western Europe, Australia and Japan would be considered non-global in our analysis.

In terms of innovativeness, firms with only "new to the firm" innovations were regarded as non-innovative. We made this choice because the survey was conducted across countries with very different levels of economic sophistication where the nature of especially "new to the firm" innovations could vary substantially (Knell and Srholec, 2009). In terms of networks, firms had to confirm that they were offshoring innovation and that at least four extra-firm partners were involved in their most important innovation of the past three years in order to be regarded as highly networked. Again reflecting our conservative approach, firms were regarded as not at all networked if only one or at most two extra-firm partners were involved in innovation.

Our conservatism extended to how we defined global innovation networks. Obviously, the 484 firms that have been coded as having neither a global footprint, nor meaningful innovation nor rich networks are excluded from the discussion. We discuss only firms with at least some level of all three indicators: global scope (g or G), innovativeness (i or I) and network scope (n or N). This represents 149 cases in the dataset. An additional 582 firms are excluded from our analysis. They include for example Indian firms that are highly global and networked, but with such trivial innovations that they have been coded as non-innovative, and highly innovative and networked European firms that are coded as non-global because their networks are all in European countries. We believe that the rigour implied by these strict criteria is useful to engender confidence in the findings of this study.

\section{Results}

\subsection{Different forms of engagement in GINs}

Of the 149 firms that participate in GINs, the most common form of engagement is as global networkers (48 firms): Firms that are highly global and highly networked, but only somewhat innovative. (See Table 6.) The next most common form is of networkers (40 firms), firms that are also highly networked, but only somewhat global and somewhat innovative. There are only five strong-form highly global, highly innovative and highly networked "Balanced GINs" in the dataset, but 28 cases where all three elements are equally present, but the values are somewhat lower. Simply looking at the number of cases, it seems that it is hard to innovate through global networks: There are many more cases that are highly global and/or highly networked than those that are highly innovative through a global network. This suggests that there may be some trade-off between managing advanced innovation, and managing extensive global networks.

Table 6: Different forms of engagement in GINs

\begin{tabular}{|l|l|l|l|l|}
\hline Type & Description & $\#$ & $\begin{array}{l}\text { \% in } \\
\text { dataset }\end{array}$ \\
\hline Global networkers & GiN & $\begin{array}{l}\text { Innovation is not as high as } \\
\text { both the globalness and the } \\
\text { networkedness. This is the } \\
\text { only common combination of } \\
\text { two stronger dimensions }\end{array}$ & $3.95 \%$ \\
\hline Networkers & giN & Strength of networks is & 40 & $3.29 \%$ \\
\hline
\end{tabular}




\begin{tabular}{|c|c|c|c|c|}
\hline & & $\begin{array}{l}\text { greater than global reach or } \\
\text { innovativeness }\end{array}$ & & \\
\hline Balanced GINs & gin & All elements in alignment & 28 & $2.30 \%$ \\
\hline Innovators & gIn & $\begin{array}{l}\text { Firms are relatively more } \\
\text { innovative than their global } \\
\text { reach or the extent of their } \\
\text { networks would suggest }\end{array}$ & 12 & $0.99 \%$ \\
\hline Global asset exploiters & Gin & $\begin{array}{l}\text { Global reach is greater than } \\
\text { the extent of innovation or } \\
\text { networkedness }\end{array}$ & 9 & $0.74 \%$ \\
\hline Networked innovators & gIN & $\begin{array}{l}\text { Highly innovative and } \\
\text { networked but not so global }\end{array}$ & 6 & $0.49 \%$ \\
\hline Strong-form balanced GINs & GIN & $\begin{array}{l}\text { Truly networked, innovative } \\
\text { and global }\end{array}$ & 5 & $0.41 \%$ \\
\hline Global asset exploiters & Gin & $\begin{array}{l}\text { Global reach is greater than } \\
\text { the extent of innovation or } \\
\text { networkedness }\end{array}$ & 1 & $0.08 \%$ \\
\hline TOTAL & & & 149 & $12.26 \%$ \\
\hline
\end{tabular}

Table 7 aggregates all 149 firms involved in GINs into a single "GIN" category, and highlights some of the salient characteristics of the overarching category. Because discussing the characteristics of different types of GINs in absolute terms can be misleading, Table 7 also provides a breakdown relative to the frequencies found in the total dataset. Take for example firm size. Almost a third of the 149 GINs (46) are firms with 50-249 employees ${ }^{12}$.

Table 7: Characteristics of combined GIN types in which firms are engaged

\begin{tabular}{|l|c|c|c|}
\hline & $\begin{array}{c}\text { Total } \\
\text { dataset }\end{array}$ & $\begin{array}{c}\text { Total of all } \\
\text { types of GINs }\end{array}$ & $\begin{array}{c}\text { \% GINs relative } \\
\text { to all firms }\end{array}$ \\
\hline Industry breakdown & & & \\
\hline Agro-processing & 133 & 15 & $11.28 \%$ \\
\hline Automotive & 146 & 10 & $6.85 \%$ \\
\hline ICT & 936 & 124 & $13.25 \%$ \\
\hline TOTAL & 1215 & 149 & $12.26 \%$ \\
\hline Location breakdown $^{\mathbf{1 3}}$ & & & \\
\hline Middle-income countries & 737 & 127 & $17.23 \%$ \\
\hline Brazil & 69 & 3 & $4.35 \%$ \\
\hline China & 243 & 8 & $3.29 \%$ \\
\hline Estonia & 17 & 0 & $0.00 \%$ \\
\hline India & 324 & 106 & $32.72 \%$ \\
\hline South Africa & 84 & 10 & $11.90 \%$ \\
\hline High-income countries & 478 & 22 & $4.60 \%$ \\
\hline
\end{tabular}

\footnotetext{
${ }^{12}$ Those 46 firms represent $15.54 \%$ of all the firms in the dataset with 50-249 employees; a greater proportion than the $12.26 \%$ of GINs in the dataset. However, proportionally this is still not as much as the $24.12 \%$ or $33.98 \%$ of the firms with $250-999$ or $1000+$ employees, even though in absolute numbers the other categories represent only 41 and 35 GINs respectively.

${ }^{13}$ Location of the unit that participates in a form of GINs
} 


\begin{tabular}{|l|c|c|c|}
\hline & $\begin{array}{c}\text { Total } \\
\text { dataset }\end{array}$ & $\begin{array}{c}\text { Total of all } \\
\text { types of GINs }\end{array}$ & $\begin{array}{c}\text { \% GINs relative } \\
\text { to all firms }\end{array}$ \\
\hline Denmark & 49 & 1 & $2.04 \%$ \\
\hline Germany & 53 & 5 & $9.43 \%$ \\
\hline Norway & 181 & 6 & $3.31 \%$ \\
\hline Sweden & 195 & 10 & $5.13 \%$ \\
\hline TOTAL & 1215 & 149 & $12.26 \%$ \\
\hline Company type & & & \\
\hline Standalone company & 693 & 57 & $8.23 \%$ \\
\hline MNC subsidiary & 246 & 60 & $24.39 \%$ \\
\hline MNC headquarters & 135 & 31 & $22.96 \%$ \\
\hline Missing values & 141 & 1 & $0.71 \%$ \\
\hline TOTAL & 1215 & 149 & $12.26 \%$ \\
\hline Firm size & & & \\
\hline$<10$ & 131 & 7 & $5.34 \%$ \\
\hline $10-49$ & 361 & 17 & $4.71 \%$ \\
\hline $50-249$ & 296 & 46 & $15.54 \%$ \\
\hline $250-999$ & 170 & 41 & $24.12 \%$ \\
\hline $1000+$ & 103 & 35 & $33.98 \%$ \\
\hline Missing values & 154 & 3 & $1.95 \%$ \\
\hline TOTAL & 1215 & 149 & $12.26 \%$ \\
\hline Significant sales abroad $\mathbf{1 4}^{\mathbf{4}}$ & & & \\
\hline No & 662 & 19 & $2.87 \%$ \\
\hline Yes & 452 & 130 & $28.76 \%$ \\
\hline Missing values & 101 & 0 & $0.00 \%$ \\
\hline TOTAL & 1215 & 149 & $12.26 \%$ \\
\hline Significant R\&D activity & & & \\
\hline No & 477 & 22 & $4.61 \%$ \\
\hline Yes & 468 & 126 & $26.92 \%$ \\
\hline Missing values & 270 & 1 & $0.37 \%$ \\
\hline TOTAL & 1215 & 149 & $12.26 \%$ \\
\hline & & & \\
\hline
\end{tabular}

Perhaps the most striking fact that is evident from Table 7 is that firms located in middle-income countries rather than in high-income countries participate in GINs that operate across both high and middle-income countries (Triad and non-Triad). Moreover, it seems that GINs are especially an India phenomenon, with a third of all the Indian firms in the dataset operating in a GIN. South Africa with close to $12 \%$ and Germany with almost $10 \%$ are the only other countries where a substantial proportion of firms participate in GINs. The German case is especially noteworthy because the automotive sector has a much lower proportion of GINs than ICT or even agro-processing.

In terms of size, the probability of being part of GINs is increases with size, but there is also evidence that small firms can be part of GINs: some $11.6 \%$ of firms with less than 1000 employees are involved in GIN, while the share of large firms (more than 1000 employees)

\footnotetext{
${ }^{14}$ Self-defined by respondents

15 Self-defined by respondents
} 
reaches 34\%.The share of firms involved in GINs is remarkably higher among those with significant foreign sales and R\&D activities, but more than $70 \%$ of firms engaged in either activity are not involved in a GIN. In addition, they do not appear as necessary conditions for being part of a GIN, since a fair proportion of firms engaged in GINs do not report substantial foreign sales or R\&D activities.

With regards to the type of firm, more than a third of the GINs are standalone firms, although proportionally MNCs (both headquarters and subsidiaries) predominate. Because the questionnaire did not address the location of subsidiaries' headquarters, it is not possible to establish whether subsidiaries are part of advanced MNCs or of so-called "emerging MNCs". However, a more detailed investigation of the location of both standalone firms and MNC headquarters (see Table 8) suggests that firms from middle-income countries are more than twice as likely to participate in global innovation networks across both middle and highincome countries than firms from high-income European countries.

Table 8: Participation in GIN for standalone firms and MNC headquarters by location

\begin{tabular}{|l|c|c|c|c|c|c|}
\hline & \multicolumn{3}{|c|}{ Standalone firms } & \multicolumn{2}{c|}{ Headquarters of MNCs } \\
\hline & $\begin{array}{c}\text { Entire } \\
\text { dataset }\end{array}$ & GINs & $\%$ & $\begin{array}{c}\text { Entire } \\
\text { dataset }\end{array}$ & GINs & $\%$ \\
\hline Middle-income countries & 349 & 40 & $11.46 \%$ & 118 & 29 & $24.58 \%$ \\
\hline Brazil & 23 & 1 & $4.35 \%$ & 2 & 0 & $0.00 \%$ \\
\hline China & 97 & 1 & $1.03 \%$ & 66 & 2 & $3.03 \%$ \\
\hline Estonia & 13 & 0 & $0.00 \%$ & 0 & 0 & $0.00 \%$ \\
\hline India & 167 & 34 & $20.36 \%$ & 50 & 27 & $54.00 \%$ \\
\hline South Africa & 49 & 4 & $8.16 \%$ & 0 & 0 & $0.00 \%$ \\
\hline High-income countries & 343 & 17 & $4.96 \%$ & 17 & 2 & $11.76 \%$ \\
\hline Denmark & 34 & 1 & $2.94 \%$ & 1 & 0 & $0.00 \%$ \\
\hline Germany & 29 & 2 & $6.90 \%$ & 4 & 1 & $25.00 \%$ \\
\hline Norway & 112 & 6 & $5.36 \%$ & 7 & 0 & $0.00 \%$ \\
\hline Sweden & 168 & 8 & $4.76 \%$ & 5 & 1 & $20.00 \%$ \\
\hline TOTAL & 692 & 57 & $8.24 \%$ & 135 & 31 & $22.96 \%$ \\
\hline
\end{tabular}

\subsection{Characteristics of the most common forms of GINs}

The most common form of GIN in which firms engage seems to be Global Networkers (GiNs): Firms that are highly global and highly networked, but only somewhat innovative. A more detailed breakdown of the characteristics of these 48 firms (see Table 6) indicates that they are typically part of MNCs(subsidiaries and especially headquarters) operating mainly in ICT. As can be expected, they are often large firms (mostly 1000+ employees), but there is also a substantial number of fairly small firms (50-249 employees).Many of these are India-headquartered, suggesting although they are MNCs, they are "emerging MNCs" that are still fairly small in terms of headcount. Even though Global Networkers represents only about $4 \%$ of the total dataset, they represent about $10 \%$ of firms with both significant R\&D activity and substantial sales abroad.

The second most common form with 40 cases is Networkers (giNs). India (as the country where the GIN participant is located) and ICT (as the industry) remain dominant, but the automotive industry becomes more prevalent. Although these firms are highly networked, they are only somewhat global and somewhat innovative. In fact, many of these firms have innovation activity within numerous countries of a single or similar region, and a coding system that did not prioritise innovation across more and less developed regions would have 
seen some categorised as Global Networkers. But it is also striking that many of them are also medium-sized (250-999 employees) standalone firms. Rather than internalise innovation activity, these firms seem to rely on dense networks of partners, often geographically not colocated, to help develop their innovations.

This same pattern is found with balanced GINs (gins). The 28 firms in this category are mostly standalone companies, and typically even smaller (50-249 employees). The importance of sales abroad and R\&D activity is smaller, although still present, and there is a more even distribution of firms from different industries and different locations, although India remains dominant.

This changes with the Innovators (gIn), accounting for about 1\% of the dataset. Although it is important to be cautious about analysing the only 12 firms in this category, a number of differences are clear. As can be expected from theory, firms from high-income countries are very well represented - proportionally, better than firms from middle-income countries and specifically India. This is also the one category where ICT is underrepresented relative to the Automotive and Agroprocessing industries, and where smaller, standalone companies predominate, suggesting that there may be some trade-off between managing advanced innovation, and managing extensive global networks. 
Table 9: Breakdown of most common forms of GINs

\begin{tabular}{|c|c|c|c|c|c|c|c|c|c|c|c|c|c|c|}
\hline \multicolumn{6}{|c|}{ Global Networkers (GiN) } & \multicolumn{3}{|c|}{ Networkers (giN) } & \multicolumn{3}{|c|}{ Balanced GINs (gin) } & \multicolumn{3}{|c|}{ Innovators (gIn) } \\
\hline & Dataset & $\begin{array}{c}\text { All } \\
\text { GINs }\end{array}$ & $\begin{array}{c}\mathrm{GiN} \\
\#\end{array}$ & $\begin{array}{c}\% \\
\text { relative } \\
\text { to all } \\
\text { GINs }\end{array}$ & $\begin{array}{c}\% \\
\text { relative } \\
\text { to } \\
\text { dataset }\end{array}$ & $\begin{array}{c}\text { giN } \\
\#\end{array}$ & $\begin{array}{c}\text { \% } \\
\text { relative } \\
\text { to all } \\
\text { GINs }\end{array}$ & $\begin{array}{c}\% \\
\text { relative } \\
\text { to } \\
\text { dataset }\end{array}$ & $\begin{array}{c}\text { gin } \\
\#\end{array}$ & $\begin{array}{c}\% \\
\text { relative } \\
\text { to all } \\
\text { GINs } \\
\end{array}$ & $\begin{array}{c}\% \\
\text { relative } \\
\text { to } \\
\text { dataset }\end{array}$ & $\begin{array}{c}\text { gIn } \\
\#\end{array}$ & $\begin{array}{c}\text { \% } \\
\text { relative } \\
\text { to all } \\
\text { GINs }\end{array}$ & $\begin{array}{c}\% \\
\text { relative } \\
\text { to } \\
\text { dataset }\end{array}$ \\
\hline \multicolumn{15}{|l|}{ Location breakdown } \\
\hline Middle-income & 737 & 127 & 45 & $35.43 \%$ & $6.11 \%$ & 38 & $29.92 \%$ & $5.16 \%$ & 21 & $16.54 \%$ & $2.85 \%$ & 6 & $4.72 \%$ & $0.81 \%$ \\
\hline Of which India & 324 & 106 & 42 & $39.62 \%$ & $12.96 \%$ & 35 & $33.02 \%$ & $10.80 \%$ & 15 & $14.15 \%$ & $4.63 \%$ & 3 & $2.83 \%$ & $0.93 \%$ \\
\hline High-income & 478 & 22 & 3 & $13.64 \%$ & $0.63 \%$ & 2 & $9.09 \%$ & $0.42 \%$ & 7 & $31.82 \%$ & $1.46 \%$ & 6 & $27.27 \%$ & $1.26 \%$ \\
\hline TOTAL & 1215 & 149 & 48 & $32.21 \%$ & $3.95 \%$ & 40 & $26.85 \%$ & $3.29 \%$ & 28 & $18.79 \%$ & $2.30 \%$ & 12 & $8.05 \%$ & $0.99 \%$ \\
\hline \multicolumn{15}{|l|}{ Industry breakdown } \\
\hline Agro-processing & 133 & 15 & 2 & $13.33 \%$ & $1.50 \%$ & 1 & $6.67 \%$ & $0.75 \%$ & 4 & $26.67 \%$ & $3.01 \%$ & 2 & $13.33 \%$ & $1.50 \%$ \\
\hline Automotive & 146 & 10 & 1 & $10.00 \%$ & $0.68 \%$ & 3 & $30.00 \%$ & $2.05 \%$ & 3 & $30.00 \%$ & $2.05 \%$ & 5 & $50.00 \%$ & $3.42 \%$ \\
\hline ICT & 936 & 124 & 45 & $36.29 \%$ & $4.81 \%$ & 36 & $29.03 \%$ & $3.85 \%$ & 21 & $16.94 \%$ & $2.24 \%$ & 5 & $4.03 \%$ & $0.53 \%$ \\
\hline TOTAL & 1215 & 149 & 48 & $32.21 \%$ & $3.95 \%$ & 40 & $26.85 \%$ & $3.29 \%$ & 28 & $18.79 \%$ & $2.30 \%$ & 12 & $8.05 \%$ & $0.99 \%$ \\
\hline \multicolumn{15}{|l|}{ Company type } \\
\hline Standalone company & 693 & 57 & 12 & $21.05 \%$ & $1.73 \%$ & 16 & $28.07 \%$ & $2.31 \%$ & 12 & $21.05 \%$ & $1.73 \%$ & 10 & $17.54 \%$ & $1.44 \%$ \\
\hline MNC subsidiary & 246 & 60 & 21 & $35.00 \%$ & $8.54 \%$ & 15 & $25.00 \%$ & $6.10 \%$ & 10 & $16.67 \%$ & $4.07 \%$ & 2 & $3.33 \%$ & $0.81 \%$ \\
\hline MNC headquarters & 135 & 31 & 15 & $48.39 \%$ & $11.11 \%$ & 9 & $29.03 \%$ & $6.67 \%$ & 5 & $16.13 \%$ & $3.70 \%$ & 0 & $0.00 \%$ & $0.00 \%$ \\
\hline Missing values & 141 & 1 & 0 & $0.00 \%$ & $0.00 \%$ & 0 & $0.00 \%$ & $0.00 \%$ & 1 & $100.00 \%$ & $0.71 \%$ & 0 & $0.00 \%$ & $0.00 \%$ \\
\hline TOTAL & 1215 & 149 & 48 & $32.21 \%$ & $3.95 \%$ & 40 & $26.85 \%$ & $3.29 \%$ & 28 & $18.79 \%$ & $2.30 \%$ & 12 & $8.05 \%$ & $0.99 \%$ \\
\hline
\end{tabular}


Table 9: Breakdown of most common forms of GINs (continued)

\begin{tabular}{|c|c|c|c|c|c|c|c|c|c|c|c|c|c|c|}
\hline \multicolumn{6}{|c|}{ Global Networkers (GiN) } & \multicolumn{3}{|c|}{ Networkers (giN) } & \multicolumn{3}{|c|}{ Balanced GINs (gin) } & \multicolumn{3}{|c|}{ Innovators (gIn) } \\
\hline & Dataset & $\begin{array}{c}\text { All } \\
\text { GINs }\end{array}$ & $\begin{array}{c}\text { GiN } \\
\#\end{array}$ & $\begin{array}{c}\% \\
\text { relative } \\
\text { to all } \\
\text { GINs } \\
\end{array}$ & $\begin{array}{c}\% \\
\text { relative } \\
\text { to } \\
\text { dataset } \\
\end{array}$ & $\begin{array}{c}\text { giN } \\
\# \\
\end{array}$ & $\begin{array}{c}\% \\
\text { relative } \\
\text { to all } \\
\text { GINs } \\
\end{array}$ & $\begin{array}{c}\% \\
\text { relative } \\
\text { to } \\
\text { dataset } \\
\end{array}$ & $\begin{array}{c}\text { gin } \\
\#\end{array}$ & \begin{tabular}{c|c}
$\%$ \\
relative \\
to all \\
GINs
\end{tabular} & $\begin{array}{c}\% \% \\
\text { relative } \\
\text { to } \\
\text { dataset }\end{array}$ & $\begin{array}{c}\text { gIn } \\
\#\end{array}$ & $\begin{array}{c}\text { \% } \\
\text { relative } \\
\text { to all } \\
\text { GINs } \\
\end{array}$ & $\begin{array}{c}\% \\
\text { relative } \\
\text { to } \\
\text { dataset } \\
\end{array}$ \\
\hline \multicolumn{15}{|l|}{ Firm size } \\
\hline Less than 10 & 131 & 7 & 1 & $14.29 \%$ & $0.76 \%$ & 1 & $14.29 \%$ & $0.76 \%$ & 1 & $14.29 \%$ & $0.76 \%$ & 2 & $28.57 \%$ & $1.53 \%$ \\
\hline $10-49$ & 361 & 17 & 12 & $70.59 \%$ & $3.32 \%$ & 6 & $35.29 \%$ & $1.66 \%$ & 5 & $29.41 \%$ & $1.39 \%$ & 3 & $17.65 \%$ & $0.83 \%$ \\
\hline $50-249$ & 296 & 46 & 19 & $41.30 \%$ & $6.42 \%$ & 12 & $26.09 \%$ & $4.05 \%$ & 15 & $32.61 \%$ & $5.07 \%$ & 4 & $8.70 \%$ & $1.35 \%$ \\
\hline 250-999 & 170 & 41 & 0 & $0.00 \%$ & $0.00 \%$ & 14 & $34.15 \%$ & $8.24 \%$ & 2 & $4.88 \%$ & $1.18 \%$ & 2 & $4.88 \%$ & $1.18 \%$ \\
\hline $1000+$ & 103 & 35 & 15 & $42.86 \%$ & $14.56 \%$ & 6 & $17.14 \%$ & $5.83 \%$ & 5 & $14.29 \%$ & $4.85 \%$ & 1 & $2.86 \%$ & $0.97 \%$ \\
\hline Missing values & 154 & 3 & 1 & $33.33 \%$ & $0.65 \%$ & 1 & $33.33 \%$ & $0.65 \%$ & 0 & $0.00 \%$ & $0.00 \%$ & 0 & $0.00 \%$ & $0.00 \%$ \\
\hline TOTAL & 1215 & 149 & 48 & $32.21 \%$ & $3.95 \%$ & 40 & $26.85 \%$ & $3.29 \%$ & 28 & $18.79 \%$ & $2.30 \%$ & 12 & $8.05 \%$ & $0.99 \%$ \\
\hline \multicolumn{15}{|c|}{ Significant sales abroad } \\
\hline No & 662 & 19 & 0 & $0.00 \%$ & $0.00 \%$ & 2 & $10.53 \%$ & $0.30 \%$ & 6 & $31.58 \%$ & $0.91 \%$ & 4 & $21.05 \%$ & $0.60 \%$ \\
\hline Yes & 452 & 130 & 48 & $36.92 \%$ & $10.62 \%$ & 38 & $29.23 \%$ & $8.41 \%$ & 22 & $16.92 \%$ & $4.87 \%$ & 8 & $6.15 \%$ & $1.77 \%$ \\
\hline Missing values & 101 & 0 & 0 & $0.00 \%$ & $0.00 \%$ & 0 & $0.00 \%$ & $0.00 \%$ & 0 & $0.00 \%$ & $0.00 \%$ & 0 & $0.00 \%$ & $0.00 \%$ \\
\hline TOTAL & 1215 & 149 & 48 & $32.21 \%$ & $3.95 \%$ & 40 & $26.85 \%$ & $3.29 \%$ & 28 & $18.79 \%$ & $2.30 \%$ & 12 & $8.05 \%$ & $0.99 \%$ \\
\hline \multicolumn{15}{|c|}{ Significant R\&D activity } \\
\hline No & 477 & 22 & 2 & $9.09 \%$ & $0.42 \%$ & 3 & $13.64 \%$ & $0.63 \%$ & 8 & $36.36 \%$ & $1.68 \%$ & 3 & $13.64 \%$ & $0.63 \%$ \\
\hline Yes & 468 & 126 & 46 & $36.51 \%$ & $9.83 \%$ & 37 & $29.37 \%$ & $7.91 \%$ & 19 & $15.08 \%$ & $4.06 \%$ & 9 & $7.14 \%$ & $1.92 \%$ \\
\hline Missing values & 270 & 1 & 0 & $0.00 \%$ & $0.00 \%$ & 0 & $0.00 \%$ & $0.00 \%$ & 1 & $100.00 \%$ & $0.37 \%$ & 0 & $0.00 \%$ & $0.00 \%$ \\
\hline TOTAL & 1215 & 149 & 48 & $32.21 \%$ & $3.95 \%$ & 40 & $26.85 \%$ & $3.29 \%$ & 28 & $18.79 \%$ & $2.30 \%$ & 12 & $8.05 \%$ & $0.99 \%$ \\
\hline
\end{tabular}


Table 10: Main characteristics of the most common forms of engagement in GINs according to origin, type and size of the firm

\begin{tabular}{|c|c|}
\hline Type of GIN & MAIN CHARACTERISTICS \\
\hline Global networkers & $\begin{array}{ll}\text { - } & \text { MNCs (both headquarters and subsidiaries) } \\
\text { - } & \text { Large firms of more than } 1000 \text { employees and some } \\
& \text { smaller firms (50-250 employees) } \\
\text { - } & \text { R\&D and global sales are very important } \\
\text { - } & \text { Dominated by India and by ICT }\end{array}$ \\
\hline Networkers & $\begin{array}{l}\text { - Both MNCs and standalone firms } \\
\text { - } \text { MNCs tend to be large, standalones tend to be between } \\
\text { 250-1000 employees } \\
\text { - } \text { R\&D and global sales are important } \\
\text { - } \quad \text { Dominated by India and by ICT } \\
\end{array}$ \\
\hline Balanced GINs & $\begin{array}{ll}\text { - } & \text { Mainly standalone firms } \\
\text { - } & \text { Mainly small-medium companies (between 50-250 } \\
\text { employees) } \\
\text { - } & \text { R\&D and global sales are somewhat important } \\
\text { - } & \text { Mostly located in middle-income countries }\end{array}$ \\
\hline Innovators & $\begin{array}{ll}\text { - } & \text { Mainly small firms } \\
\text { - } & \text { Mainly stand-alone firms } \\
\text { - } & \text { R\&D very important, global sales somewhat important } \\
\text { - } & \text { Mostly located in high-income countries with industries } \\
& \text { evenly distributed }\end{array}$ \\
\hline
\end{tabular}

\section{Discussion}

5.1. Middle income countries innovation systems and GINs

Firms located in systems of innovation in middle-income countries seem at least as likely as firms located in higher-income countries to participate in GINs, with the strong participation from India skewing the results strongly towards middle-income countries. To understand this, it is perhaps useful to recall that engaging in global networks is costly firms need to develop strategies and protocols to communicate and coordinate as complex and fluid an activity as innovation across multiple boundaries. It stands to reason that firms will only engage in GINs if the cost of innovation through a global network is lower and benefits greater than finding the resources needed for innovation locally. This can happen when firms are especially innovative and used to operating through a complex network (the well-documented case of the established MNCs from advanced economies), or as a compensation mechanism of firms from a somewhat disadvantaged context.

Previous research has found that firms from middle-income countries may internationalise in response to institutional voids (Elango \& Pattnaik, 2007; Stal \& CuervoCazurra, 2011). Firms in a scarce skills context may be forced to outsource extensively, including to partners from distant locations if they are geographically at a distance from leading service providers. Many of the firms using GINs as a compensatory mechanism are also used to operating through business networks in order to overcome institutional voids (Chaminade \& Plechero, 2014)

In this regard, it is noteworthy to consider how central GINs are to the strategies of Indian firms. Granted, the survey polled ICT firms and innovation through global networks is 
obviously facilitated by the fact that global reach and networking are easier to accomplish in ICT than in other industries. But the same importance of GINs was not found in any of the other countries where ICT was the focus of the survey, like Sweden, Norway or China. Not only are more than two-thirds of the firms represented in GINs from India, but a third of all the Indian firms polled participated in GINs. This suggests that firm strategy matters: India is English-speaking, is a popular outsourcing destination for established MNCs, and domestic Indian firms often target the global market first. In contrast, China and Norway experience not only language barriers, but there is also a stronger domestic focus among IT firms.

\subsection{GINs as an emerging form of openess}

Standalone firms, MNC headquarters and subsidiaries all participate in GINs. The wide range of firm types involved with GINs suggests that GINs cannot be simply seen as an example of the further internationalisation of R\&D or as the evolutionary upgrading of global production networks, both phenomena highly dependent on advanced MNCs. Instead, it deserves to be investigated as an emerging phenomenon with many facets.

While this paper does provide evidence of MNCs from high-income countries participating in networks that span higher and lower income countries in order to innovate there is also evidence of standalone firms and emerging MNCs participating in such networks. In some cases, such firms may have been part of GPNs - the majority of firms participating in GINs have substantial sales activity abroad - and innovation activities may reflect capability upgrading, such as identified by Ernst (2010). But more than $12 \%$ of the GINs do not have substantial sales activity abroad, and their participation in global networks seems to be purely for the sake of innovation.

Furthermore, our evidence suggests that GINs are not exclusively an ICT phenomenon. Research suggests that ICT can facilitate the emergence of GINs (Rangan \& Sengul, 2009), but firms from the other two industries (agro-processing and automotive) also participate in GINs. In fact, certain types of GINs, notably highly innovative networks, are dominated by other industries.

\subsection{Methodological limitations}

It is important to note that although the paper deals with openness of innovation systems through global innovation networks, what is polled is not the network, but a single node of the network. The evidence is best described as an "ego network", and it suffers from the typical shortcomings of ego networks. The evidence is self-reported, and respondents are likely to provide more accurate information on local matters (e.g. the number of people employed at that unit) than on more distant matters (e.g. the size of the organisation overall).

Another issue of concern is ownership and control. Specifically related to the strong representation of firms from middle-income countries, the evidence does not allow us to adequately distinguish between a subsidiary which is part of a GIN because it is part of the complex network of an advanced MNC, and a subsidiary that creates and uses a strong-form GIN to compensate for not only a weaker institutional context, but also the absence of the advanced MNC's rich network. Although this concern is mitigated by looking at standalone firms and MNC headquarters, if participation in a GIN can be regarded as a form of created asset seeking, it is not possible to establish whether the motive lies with the unit in the responding location or with the parent.

This is particularly consequential because this is a cross-sectional questionnaire, and because firm motives evolve. We can map the participation in GINs at this point in time, but the relative importance of different firm types, sizes of firms and locations of units is likely to change over time. This paper therefore reveals evidence about GINs at a fairly early point of their evolution. 
The constructs of network scope and innovativeness can also be interpreted in alternative ways. In their study of business ties in Argentina, (McDermott \& Corredoira, 2009) point out that the number of links does not necessarily translate into the value of those ties. It cannot be ruled out that firms from high-income countries may have fewer ties but have learnt to use them more strategically than firms from middle-income countries. Similarly, when assessing the novelty of a given innovation, an entity in the less developed world may judge it relative to other innovations in its less developed context, and judge it as more innovative than an entity in Europe would, since new-to-the-world innovations are more common there.

This shortcoming relates to the substantial challenges of conducting and interpreting a standardised survey across very different countries and industries. In spite of considerable efforts to ensure concordance between different countries and different industries, there are considerable differences in the types of databases used and response rates between countries. At a conceptual level, it must be asked to what extent even "objective" measures like the number of people working in a firm in two contexts as different as, for example, Denmark and India, can be regarded as comparable.

Finally, our data explores the openness of national innovation systems derived from micro-level data and the behaviour of firms located in national innovation systems. Our results suggest that it is firms located in NSI in middle income countries which show a higher propensity to engage in networks that are truly innovative and global thus suggesting that those NSI might show higher degrees of openness through GINs. However, GINs are only one form of mechanism through which firms and other organizations in NSI can acquire, exchange and generate knowledge with international and global partners. Other mechanisms are trade, mobility of human capital, licensing, etc. Ultimately the openness of a NSI should be measured and captured by looking at a variety of mechanisms beyond innovation networks.

\section{Conclusions}

The results of this paper challenge some of the assumptions in the literature and opens up several avenues for future research. The research complements the hitherto advanced MNCcentred literature on the internationalization of innovation and global production networks, and suggests that the focus on advanced MNCs as the sole drivers of openness of innovation systems through GINs is too limited. While there is considerable evidence in this paper of GINs being driven by MNCs from the leading economies, further contributing to the considerable body of extant work to support the importance of the MNC as a vehicle for cross-border networks, our paper also provides clear evidence of both emerging MNCs and stand-alone firms participating in GINs.

Our evidence suggests that emerging MNCs (e.g. those headquartered in India) rely as heavily as MNCs from the leading economies on GINs. The motives for their participation in GINs are an area deserving of additional research, but it seems unlikely that GIN participation reflects the exploitation of additional capabilities. Instead, the emerging MNCs are likely to use networks to access additional capabilities.

Our paper does not provide the first evidence of the internationalisation of nonMNCs: The work on "born globals" (Knight \& Cavusgil, 2004) and work arguing that SMEs can benefit from outsourcing (Stal \& Cuervo-Cazurra, 2011), both indicate that smaller and stand-alone firms can form global networks. Our findings suggest that such loose global networks (that seem to be governed by contracts rather than the hierarchy of the MNC) do evolve to enable innovation.

Related, GINs seem to serve two main purposes: one purpose, found among the leading MNCs, is that GINs may act as a way to accelerate innovation, complementing 
existing R\&D at the headquarters (Davide Castellani \& Pieri, 2013). The other purpose is as a compensatory mechanism when firms have limited resources. To the extent that emerging MNCs and non-MNCs use global networks to compensate for limited in-house capabilities, GINs function not as a way to accelerate innovation, but rather as a way to "level the playing field".

For policymakers, the core insight of this study is that GINs weaken the link between the munificence of a location and the strength of firms from that location. Because firms can access the most appropriate capabilities and resources wherever in the world they are found, it is possible for "strong" firms to emerge from "weak" locations. This has different implications for policy makers in more versus less developed countries.

Because they can and do source so many of their needed capabilities from abroad, firms have the option of being only loosely connected to their home location and policymakers need to develop strategies to ensure that firms remain locally connected. This includes conducting additional research to establish in which ways their home location can benefit from firms engaged in global innovation networks, while still giving them the freedom to source capabilities from the most appropriate context.

Although NSI in high-income countries often house firms from other locations, their home-grown firms seem almost paradoxically less globally connected. Supported by a welldeveloped institutional infrastructure, the European firms seem to have a regional or domestic (rather than global) focus, and (perhaps as a consequence) a limited span of networks. While this seems to be positive for innovation at the moment, too much focus on regional networks can lead to lock-ins and loss of competitiveness in the long term. Because of the cooccurrence of innovation with global scope and network scope, this trend could even limit their longer-term innovativeness. It is therefore important to identify the triggers that challenge firms to engage in global innovation networks.

Finally, it is important to note that global innovation networks are a rather new phenomenon that is changing very rapidly. As regions in middle-income countries accumulate innovation capabilities, we may witness, for example, a decrease in the need to connect globally and a gradual turn toward less networked, less global but more innovative GINs originating from those national innovation systems. Or we may witness a fundamental change in the way firms are organised, comparable to the emergence of the multidivisional firm documented by (Chandler, 1962). Ongoing research on a global scale is needed to track how this form of organising evolves.

Acknowledgements: Research for this paper was partially funded by the European Community's Seventh Framework Programme (Project INGINEUS, Grant Agreement No.225368, www.ingineneus.eu, the Swedish Research Council (Linneaus grant) and the Marianne and Marcus Wallenberg's Foundation, grant number MMW 2012.0194 is acknowledged. We are grateful for the comments provided by the participants of the INGINEUS Copenhagen workshop to an earlier version of this paper. The usual disclaimer applies.

\section{7. $\quad$ References}

Amighini, Alessia, Sanfilippo, M., \& Rabellotti, Roberta. (2010). The rise of multinationals from emerging countries: A review of the literature. . SEMeQ - Università del Piemonte Orientale.

Archibugi, D., \& Michie, J. (1995). The globalisation of technology: a new taxonomy. Cambridge Journal of Economics, 19(1), 121. 
Barnard, Helena. (2011). Emerging centres of excellence: Knowledge-sharing between developing country firms and their subsidiaries in the developed world. Innovation and Development, , 1(2), 235-251.

Bell, M., \& Pavitt, K. (1993). Technological accumulation and industrial growth: contrasts between developed and developing countries. Industrial and corporate change, 2(2), 157-210.

Bell, Martin, \& Pavitt, Keith. (1995). The Development of Technological Capabilities. In Irfan Haque (Ed.), Trade, Technology and International Competitiveness (pp. 69-101). Washington: The World Bank.

Cantwell, J. (2000). The Role of Multinational Corporations and National States in the Globalization of Innovatory Capacity: The European Perspective. Technology Analysis \& Strategic Management,, 12(2), 243-262.

Cantwell, J., \& Janne, O. (1999). Technological globalisation and innovative centres: the role of corporate technological leadership and locational hierarchy. Research Policy, 28(2), 119-144.

Cantwell, J., \& Piscitello, L. (2002). The location of technological activities of MNCs in European regions: the role of spillovers and local competencies. Journal of International Management, 8(1), 69-96.

Cantwell, J., \& Piscitello, L. (2005). Competence-creating vs. Competence-exploiting Activities of Foreignowned MNCs: How Interaction with Local Networks Affects their Location. Paper presented at the Annual Conference of the European International Business

Cantwell, J., \& Santangelo, G. D. (2002). The new geography of corporate research in Information and Communications Technology (ICT). Journal of Evolutionary Economics, 12(1), 163-197.

Cantwell, John. (2004). Innovation and competitiveness. In J. FAGERBERG, D. MOWERY, \& R. NELSON (Eds.), The Oxford handbook of innovation (pp. 543-567). Oxford: OUP.

Cantwell, John, \& Odile, Janne. (2000). The Role of Multinational Corporations and National States in the Globalization of Innovatory Capacity: The European Perspective. Technology Analysis \& Strategic Management, 12(2), 243-262.

Cantwell, John, \& Piscitello, Lucia. (2005). Recent Location of Foreign-owned Research and Development Activities by Large Multinational Corporations in the European Regions: The Role of Spillovers and Externalities. Regional Studies, 39(1), 1-16.

Cantwell, John, \& Piscitello, Lucia. (2007). Attraction and Deterrence in the Location of Foreign/owned R\&D activities: the role of positive and negative spillovers. International Journal of Technological Learning, Innovation and Development, 1(1), 83-111. 
Castellacci, F., \& Archibugi, D. (2008). The technology clubs: The distribution of knowledge across nations. Research Policy, 37(10), 1659-1673.

Castellani, D., \& Zanfei, A. (2006). Multinational firms, innovation and productivity: Edward Elgar Cheltenham.

Castellani, Davide, \& Pieri, Fabio. (2013). R\&D offshoring and the productivity growth of European regions. Research Policy, 42(9), 1581-1594.

Chaminade, C., \& Plechero, M. (2014). Do regions make a difference? Regional innovation systems in global innovation networks in the ICT industry. European Planning Studies, published online on 12 march 2014 - OI:

10.1080/09654313.2013.861806.

Chaminade, C., \& Vang, J. (2008). Globalisation of knowledge production and regional innovation policy: Supporting specialized hubs in the Bangalore software industry. Research Policy, 37(10), 1684-1696.

Chandler, A.D. Jr. (1962). Strategy and Structure: Chapters in the History of the American Industrial Enterprise. Cambridge, MA: MIT Press.

Coe, N.M., \& Bunnell, T.G. (2003). 'Spatializing'knowledge communities: towards a conceptualization of transnational innovation networks. Global networks, 3(4), 437456.

Cooke, Philip. (2013a). Global production networks and global innovation networks: Stability versus growth. European Planning Studies, 21(7), 1081-1094.

Cooke, Philip. (2013b). Qualitative Analysis and Comparison of Firm and System Incumbents in the New ICT Global Innovation Network. European Planning Studies, 21(9), 1323-1340. doi:10.1080/09654313.2012.755828

Dedrick, Jason, Kraemer, Kenneth L, \& Linden, Greg. (2009). Who profits from innovation in global value chains?: a study of the iPod and notebook PCs. Industrial and corporate change, 19(1), 81-116.

Dicken, Peter. (2007). Global Shifts: mapping the changing contours of the world economy ( 5th Edition ed.). New York: Guilford.

Dunning, J.H., \& Lundan, S.M. (2009). The Internationalization of Corporate R\&D: A Review of the Evidence and Some Policy Implications for Home Countries1. Review of Policy Research, 26(1 - 2), 13-33.

Edquist, C. (2005). Systems of innovation: perspectives and challenges. The Oxford handbook of innovation(7), 181-208.

Elango, B., \& Pattnaik, C. (2007). Building capabilities for international operations through networks: a study of Indian firms. Journal of International Business Studies, 38(4), 541-555.

Ernst, Dieter. (2009). A new geography of knowledge in the electronics industry?: Asia's role in global innovation networks. 
Fifarek, B.J., \& Veloso, F.M. (2010). Offshoring and the global geography of innovation. Journal of Economic Geography, 10(4), 559.

Gertler, M. S., \& Levitte, Y. M. (2005). Local Nodes in Global Networks: The Geography of Knowledge Flows in Biotechnology Innovation. Industry and Innovation, 12(4), 487507.

Gerybadze, A., \& Reger, G. (1997). Globalisation of $R$ \& D: Recent Changes in the Management of Innovation in Transnational Corporations. Discussion Paper on International Management and Innovation. Forschungsstelle Internationales Management und Innovation. Stuttgart. Retrieved from http://www.econbiz.de/archiv/s/uhoh/internationales management/globalisation $r$-d.pdf

Hagedoorn, J. (1993). Understanding the Rationale of Strategic Technology Partnering Interorganizational Modes of Cooperation and Sectoral Differences. Strategic Management Journal, 14(5), 371-385.

Hagerdoorn, J. (1990). Organisational modes of inter-firm cooperation and technology transfer. Technovation, 10(1), 17-30.

Howells, J. (1990). The internationalization of R \& D and the development of global research networks. Regional Studies, 24(6), 495-512.

Knight, G.A., \& Cavusgil, S.T. . (2004). Innovation, Organizational Capabilities, and the Born-Global Firm. Journal of International Business Studies, 35(2), 124-141.

Kuemmerle, W. (1999). The Drivers of Foreign Direct Investment into Research and Development: An Empirical Investigation. Journal of International Business Studies, 30(1), 1-2.

Le Bas, Christian, \& Sierra, Christophe. (2002). Location versus Home Country Advantages in R\&D Activities: Some Further Results on Multinationals Locational Strategies. Research Policy, 31(4), 589-609.

McDermott, Gerald A., \& Corredoira, Rafael A. (2009). Network composition, collaborative ties, and upgrading in emerging-market firms: Lessons from the Argentine autoparts $\begin{array}{llllll}\text { sector. } & J & \text { Int } & B u s & \text { Stud, } & \text { 41(2), }\end{array}$ doi:http://www.nature.com/jibs/journal/v41/n2/suppinfo/jibs20097s1.html

Narula, R., \& Hagedoorn, J. (1999). Innovating through strategic alliances: Moving towards international partnerships and contractual agreements. Technovation, 19(5), 283-294.

Narula, Rajneesh, \& Zanfei, Antonello. (2004). Globalization of innovation: the role of multinational enterprises. In J. FAGERBERG, D. MOWERY, \& R. NELSON (Eds.), The Oxford handbook of innovation (pp. 318-347). Oxford: OUP.

OECD. (2008). Open Innovation in Global Networks. Retrieved from

Parrilli, Mario Davide, Nadvi, Khalid, \& Yeung, Henry Wai-Chung. (2013). Local and Regional Development in Global Value Chains, Production Networks and Innovation 
Networks: A Comparative Review and the Challenges for Future Research. European Planning Studies, 21(7), 967-988. doi:10.1080/09654313.2013.733849

Pearce, R. D. (1999). Decentralised R\&D and strategic competitiveness: globalised approaches to generation and use of technology in multinational enterprises (MNEs)

. Research Policy, 28, 157-188.

Ramamurti, R. , \& Singh, J. (2009). Emerging multinationals in emerging markets. Cambridge, UK: Cambridge University Press.

Rangan, Subramanian, \& Sengul, Metin. (2009). Information technology and transnational integration: Theory and evidence on the evolution of the modern multinational enterprise. J Int Bus Stud, 40(9), 1496-1514.

Rodriguez, A. (2011). Offshoring of R\&D: Looking abroad to improve innovation performance. Journal of International Business Studies, 42(3), 345-361.

Sabiola, Federica, \& Zanfei, A. (2009). Multinational firms, global value chains and the organization of knowledge transfer. Research Policy, 38, 369-381.

Saliola, Federica, \& Zanfei, A. (2009). Multinational firms, global value chains and the organization of knowledge transfer. Research Policy, 38, 369-381.

Stal, Eva, \& Cuervo-Cazurra, Alvaro. (2011). The Investment Development Path and FDI From Developing Countries: The Role of Pro-Market Reforms and Institutional Voids. Latin American Business Review, 12(3), 209-231. doi:10.1080/10978526.2011.614174

Timmer, Marcel P, Erumban, Abdul Azeez, Los, Bart, Stehrer, Robert, \& de Vries, Gaaitzen J. (2014). Slicing up global value chains. The Journal of Economic Perspectives, 28(2), 99-118.

UNCTAD. (2006). World Investment Report. FDI from Developing and Transition Economies: Implications for Development. Retrieved from

Yeung, Henry Wai- chung, \& Coe, Neil M. (2014). Toward a Dynamic Theory of Global Production Networks. Economic Geography.

Zander, I. (1999). How do you mean [] global'? An empirical investigation of innovation networks in the multinational corporation. Research Policy, 28(2-3), 195-213. 